\title{
Modeling of Structure Evolution During Hot Rolling of Aluminum Alloys in the Software Package DEFORM
}

\author{
Vasiliy V. Yashin a, Maksim S. Tepterev*a, \\ Evgeniy V. Aryshensky ${ }^{\mathrm{b}}$ and Vadim V. Kolotilin ${ }^{\mathrm{b}}$ \\ "ZAO "Alcoa SMZ" \\ 29 Alma-Atinskaya, Samara, 443051, Russia \\ ${ }^{b}$ Samara State Aerospace University \\ 45 Moskovskoye shosse, 443086, Russia
}

Received 14.03.2016, received in revised form 02.07.2016, accepted 08.08.2016

The study provides modeling of aluminum alloy 5182 BT (Al-Mg 4,5\%) structure evolvement during hot rolling in each stand of 5-stand continuous hot rolling mill. Mathematical modeling was made in DEFORM software product, Johnson-Mehl-Avrami-Kolmogorov equation was used for recrystallization kinetics setup. DEFORM enables to consider recrystallization of three types: dynamic, meta-dynamic and static recrystallization. Proceeding from actual rolling process temperature and speed parameters, the task was converted to static recrystallization calculation. Input coefficients were taken from literature data review. The output is volume of recrystallized grains and their sizes calculated throughout the rolling process.

Description of processes related to grain size changes in rolling aluminum alloys is peculiar due to lack of consistent patterns. This is explained by the fact that grain growth during rolling is influenced by many factors associated with both internal metal structure and individual process specifics. That is why modeling results should be compared with industrial experimental data. In this case, texture and structure evolvement data received as a result of Hot Rolling Mill 2800 forced stop with subsequent quenching of metal were used for comparison.

Keywords: modeling, hot rolling, structure, aluminium, deform, anithtrophy, recristallization, ZennerHolomon option, Avrami-Kolmogorov equation.

Citation: Yashin V.V., Tepterev M.S., Aryshensky E.V., Kolotilin V.V. Modeling of structure evolution during hot rolling of aluminum alloys in the software package deform, J. Sib. Fed. Univ. Eng. technol., 2016, 9(6), 830-835. DOI: 10.17516/1999494X-2016-9-6-830-835.

(C) Siberian Federal University. All rights reserved

* Corresponding author E-mail address: Maksim.Tepterev@alcoa.com 


\title{
Моделирование эволюции структуры
}

\section{при горячей прокатке алюминиевых сплавов \\ в программном комплексе DEFORM}

\author{
В.В. Яшин ${ }^{\mathrm{a}}$, М.С. Тептерев ${ }^{\mathrm{a}}$, \\ Е.В. Арышенский ${ }^{\sigma}$, В.В. Колотилин ${ }^{\sigma}$ \\ а ЗАО «Алкоа СМЗ» \\ Россия, 443051, Самара, ул. Алма-Атинская, 29 \\ ${ }^{6}$ Самарский государственный аэрокосмический университет \\ Россия, 443086, Самара, Московское шоссе, 45
}

В статье проведено моделирование эволюции структуры при горячем прокате алюминиевого сплава 5182 БТ (Al-Mg4,5\%) в каждой клети пятиклетьевой непрерывной группы стана горячей прокатки. Математическое моделирование проводилось в программном продукте Deform, для задания кинетики рекристаллизации использовалось уравнение ДжонсонаМела-Аврами-Колмогорова. DEFORM позволяет учитывать рекристаллизацию трех типов: динамическую, метадинамическую и статическую. Исходя из реальных температурноскоростных параметров процесса прокатки, задача была сведена к расчету статической рекристаллизации. Исходные коэффициенты были взяты из анализа литературных данных. B результате рассчитан объем рекристаллизованных зерен и их размеры на протяжении всего прочесса прокатки.

Особенностью описания процессов, связанных с изменением размеров зерна при прокатке алюминиевых сплавов, является отсутствие устойчивых закономерностей. Это объясняется тем, что на рост зерна при прокатке влияет значительное количество факторов, связанных как с внутренним строением металла, так и с особенностями конкретных технологических проиессов. Поэтому результаты моделирования необходимо сопоставлять с данными промышленных экспериментов. В нашем случае для сравнения использовались данные о эволюиии текстуры и структуры, полученные в результате принудительной остановки стана горячей прокатки «2800» с последующим резким охлаждением металла.

Ключевые слова: моделирование, горячая прокатка, структура, алюминий, деформ, анизотропия, рекристаллизачия, параметр Зеннера-Холомона, уравнение КолмогороваАврами.

\section{Introduction}

Currently aluminum is a most optimal material to manufacture many types of food containers. The global competition requires that manufacturers would conduct ongoing improvements of mechanical properties and weight reduction of aluminum food containers. One of the reasons hindering it is anisotropy of cold rolled sheets and coils. It makes stamping process less stable and can lead to different defects during production of various food containers.

\section{Experiment}

Control of metal texture [1,2] is a key to reduce anisotropy. Also solutions of this task require knowledge of structure evolution at various stages of sheet production. Important issues, for example, are investigation of recrystallization during inter-deformation intervals and self-annealing after hot rolling. To solve them, a lot of models describing kinetics of aluminum alloy recrystallization have 
been created for the last 20 years [5-8]. They are mainly based on Kolmogorov-Avrami equation. However, their weakness is in absence of verification at actual industrial equipment. Additional doubts are raised by the fact that these models were built mainly based on compression tests, but strain-stress state and other conditions of it differ considerably from those that occur on rolling mill.

The goal of this work is to verify applicability to the rolling process of recrystallization kinetics model for aluminum alloy 5182 proposed in [8]. For this purpose, structure formation in continuous hot rolling mill group was simulated in Deform. The simulation results were compared with earlier obtained industrial experiment data.

It should be noted, that due to insufficient strain rate, there is no dynamic and metadynamic recrystallization in most of alloys during hot rolling. Therefore, in this case we considered only static recrystallization, development of which is described in DEFORM by Avrami equation:

$$
X_{S R X}=1-\exp \left[-\beta_{S} \cdot\left(\frac{t}{t_{0.5}}\right)^{k s}\right]
$$

where $X_{S R X}-$ fraction of recrystallized volume; $\mathrm{t}$-holding time; $\mathrm{t}_{05}$ - time during which $50 \%$ of metal volume is recrystallized.

The $\beta_{s}$ is proportionality coefficient andksreflect influence of spatial factor nucleuses formation and growth for 5182 alloy recrystallization according to [6], $\beta_{s}=0.693$, $\mathrm{ks}=2$.

It is proposed to use the equation below to obtain $\mathrm{t}_{0.5}$ in DEFORM.

$$
t_{05}=a_{3} d^{h_{3}} \varepsilon^{n_{3}} \dot{\varepsilon}^{m_{3}} \exp \left(\frac{Q_{3}}{R T}\right),
$$

where $\mathrm{Q}_{3}$ - recrystallization activation energy for alloy 5182 equal to 230,000 according to [8]; $\mathrm{T}$ - material temperature; $R$ - universal gas constant;

However, according to the work [8] time of recrystallization development does not depend neither on grain size nor on level of previous deformation, that is why coefficients $h_{3}$ and $n_{3}$ are set to zero. The recrystallization process itself can be described according to equation (3).

$$
t_{0.5}=a \cdot Z^{b} \cdot \exp \left(\frac{E_{r}}{R \cdot T_{h}}\right)
$$

where $E_{r}$ is also recrystallization activation energy.

Coefficients, in equation (2) are found from equating right parts of (2) and (3) . Then assuming that $\mathrm{m}_{3}=\mathrm{b}$ и $\mathrm{a}_{3}=\mathrm{a}$

$$
a_{3} \dot{\varepsilon}^{m_{3}}=a Z^{b}
$$

where, $Z$ is Zener-Hollomon parameter;

Zener-Hollomon parameter is the temperature compensated strain rate and determined as follows:

$$
Z=\varepsilon \cdot \exp \left(\frac{Q_{d e f}}{R \cdot T_{d e f}}\right)
$$

where $Q_{d e f}$ deformation activation energy $=174,200 ; T_{\text {def }}$ deformation temperature.

Then we obtain:

$$
m_{3}=b=-1.267 ;
$$




$$
a_{3}=7.772 \cdot\left[\exp \cdot\left(\frac{174200}{8.314 \cdot T_{\text {def }}}\right)\right]-1.267
$$

Therefore, coefficient $\mathrm{a}_{3}$ depends on deformation temperature and can be represented in DEFORM as a table.

Calculations for 5182 alloy sheets for hot rolling in continuous mill group were made with these recrystallization parameters according to rolling pass schedule (Table 1).

It was assumed that all grains that had been recrystallized earlier, undergo certain plastic deformation in current pass. All process parameters of simulation had same values as parameters of industrial experiments that had been carried out earlier [3,9]. It should be noted that the continuous rolling mill, operation of which was simulated in DEFORM, actually has 5 stands. However, simulation of the last stand does not make sense because after it occurs self-annealing with full recrystallization.

The 5182 alloy calculation results (Fig. 1,2) are predictable enough and as a whole do not contradict general conceptions that aluminum alloys with high content of Magnesium and without low solubility impurities which have tendency to intensify static recrystallization [4]. It can be explained by their high stacking fault energy (SFE).

Table 1. Rolling pass schedule for 5182 alloy ingots in 5 stand group

\begin{tabular}{|c|c|c|c|c|c|}
\hline \multirow{2}{*}{ Stand \# } & \multicolumn{2}{|c|}{ Thickness, $\mathrm{mm}$} & Stand speed, $\mathrm{m} / \mathrm{s}$ & Temperature, ${ }^{\circ} \mathrm{C}$ & $\begin{array}{c}\text { Time between } \\
\text { stands, } \mathrm{c}\end{array}$ \\
\cline { 2 - 5 } & Entry & Exit & & 450 & \multirow{2}{*}{11} \\
\hline 1 & 35 & 19.55 & 0.53 & 400 & 6 \\
\hline 3 & 19.55 & 11.79 & 1 & 375 & \multirow{2}{*}{3} \\
\hline 4 & 11.79 & 6.99 & 1.75 & 360 & 3 \\
\hline
\end{tabular}

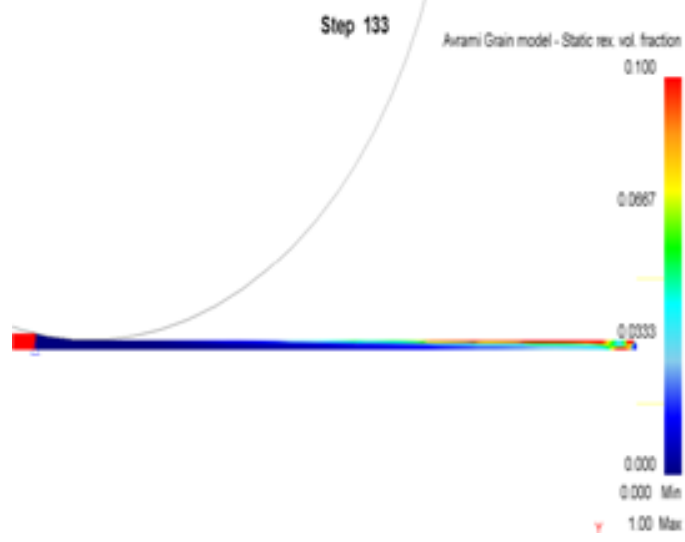

a

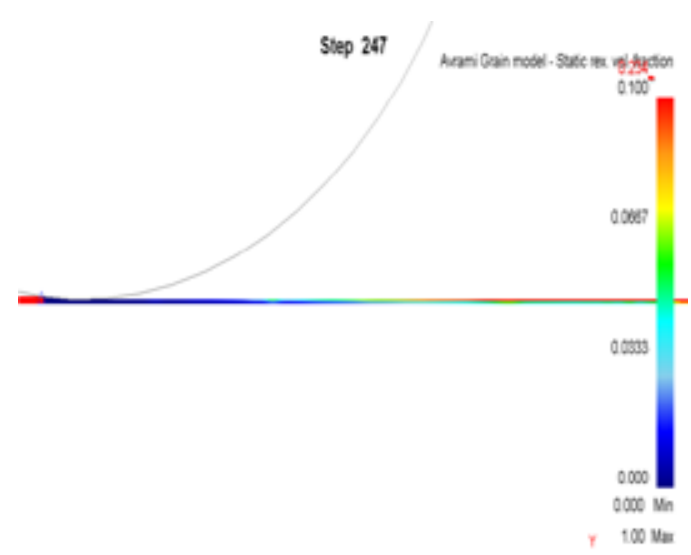

b

Fig. 1. Recrystallization kinetics: a) 5182 transient gauge sheet microstructure after the $2^{\text {nd }}$ stand of continuous group; b) after the $4^{\text {th }}$ stand of continuous group 


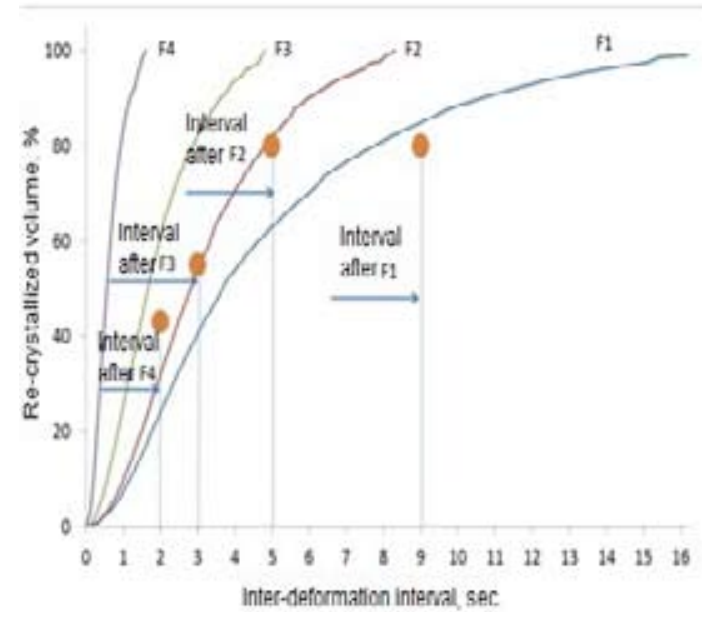

Fig. 2. Comparison of calculation results with experimental data

However, in spite of the fact that the general principles of recrystallization kinetics for 5182 alloy described in [8] are true, but actual recrystallization parameters cannot be applied to engineering calculations of rolling processes. It is proven by comparison of simulation data with actual industrial experiment results. The main difference is in overestimation of recrystallization speed in the work [8] and if deviations for the first two stands are acceptable for engineering calculations, considerable differences between simulation and experiment are found in the third and forth stands. Such condition is apparently a result of overestimated influence of strain rate on recrystallization kinetics. Its influence in the model is actually not compensated neither by time reduction of inter-deformation interval nor by temperature drop.

\section{Conclusions}

1. The approach with use of Kolmogorov-Avrami equation in simulation of recrystallization processes in aluminum alloys with high content of Magnesium during hot rolling in general is effective.

2. However the influence of strain rate on recrystallization kinetics is evidently overestimated in the existing model. Therefore the model of static recrystallization development in 5182 alloy requires further elaboration and cannot be used for calculations of industrial rolling process.

\section{References}

[1] Смирнов В.С., Дурнев В.Д. Текстурообразование металлов при прокатке, М.: Металлургия, 1971, 256 c. [Smirnov V.S., Durnev V.D. Teksturoobrazovanie metallov pri prokatke, M.: Metallurgiya, 1971, 256 s.]

[2] Арышенский Ю.М., Гречников Ф.В., Арышенский В.Ю. Получение рациональной анизотропии в листах, М.: Металлургия, 1987, 141 с. [Aryshenskii U.M., Grechnikov F.V., Aryshenskii V.Y. Poluchenie ratsionalnoy anizotropii v listah, M.: Metallurgiya, 1987, 141 s.]

[3] Арышенский Е.В., Беглов Э.Д., Гречникова А.Ф. Получение рациональной анизотропии в сплаве 5182 при горячей прокатке в полунепрерывных станах, Tpyды международного научно- 
технического конгресса «ОМД-2014», М.: ООО «Белый Ветер», 2014, 254 - 262. [Aryshenskii E.V., Beglov E.D., Grechnikova A.F. Poluchenie ratsionalnoy anizotropii v splave 5182 pri goryache prokatke $\mathrm{v}$ polynepreryvnih stanah, Trudy mezhdunarodnogo nauchno-tehnicheskogo kongressa «OMD-2014», M.: OOO «Belyj Veter», 2014, 254 - 262.]

[4] Вайнблат Ю.М., Шаршагин Н.А., Варфоломеева Э.А. Диаграммы структурных состояний и механизмов деформации алюминиевых сплавов. М.: ВИЛС, 1985. 123 с. [Vajnblat Ju.M., Sharshagin N.A., Varfolomeeva Je.A. Diagrammy strukturnyh sostojanij i mehanizmov deformacii aljuminievyh splavov. M.: VILS, 1985. 123 s.]

[5] Raghunathan N., Sheppard T. Microstructural development during annealing of hot rolled Al-Mg alloys, Mater. Sci. Technol., 1989, 542-547.

[6] Wells M.A., Maijer D.M., Jupp S., Lockhart G., van der Winden M.R. Mathematical model of deformation and microstructural evolution during hot rolling of aluminium alloy 5083, Mater. Sci. Technol., 19 (4), 2003, 467-476.

[7] Aryshenskii E.V., Aryshenskii V.Y., Grechnikova A.F., Beglov E.D. Evolution of Texture and Microstructure in the Production of Sheets and Ribbons from Aluminum Alloy 5182 in Modern Rolling Facilities Source of the Document, Metal Science and Heat Treatment, 56 (7 - 8), 347 - 352.

[8] YI You-ping, FU Xin, CUI Jin-dong, CHEN Hua, Prediction of grain size for large-sized aluminium alloy 7050 forging during hot forming, Journal of Central South University of Technology, 2008, 15(1), 1-5.

[9] Zhang H., Peng D.S., Yang L.B., Meng L.P. Recrystallization model for hot-rolling of 5182 aluminum alloy, Transactions of Nonferrous Metals Society of China (English Edition), 11 (3), 2001, 382-386. 